\title{
UV-C effect on microbial disinfection of pineapple-mango juice blend using Dean-vortex technology
}

\author{
${ }^{1}$ Amanina, A.K.Z., ${ }^{1,3 *}$ Rosnah, S., ${ }^{2}$ Noranizan, M.A. and ${ }^{1}$ Alifdalino, S. \\ ${ }^{1}$ Department of Process and Food Engineering, Faculty of Engineering, Universiti Putra Malaysia, 43400, \\ UPM Serdang, Selangor, Malaysia. \\ ${ }^{2}$ Department of Food Technology, Faculty of Food Science and Technology, Universiti Putra Malaysia, \\ 43400, UPM Serdang, Selangor, Malaysia. \\ ${ }^{3}$ Institut Teknologi Maju (ITMA), Universiti Putra Malaysia, 43400, UPM Serdang, Selangor, Malaysia.
}

\begin{abstract}
Article history:
November 2018

November 2018

Keywords:

UV-C,

Pineapple,

Mango,

Juice blend,

Dean-vortex
\end{abstract}

Received: 28 May 2018

Received in revised form: 12

Accepted: 12 November 2018

Available Online: 20

DOI:

https://doi.org/10.26656/fr.2017.3(4).113

\begin{abstract}
This study intended to evaluate the effect of ultraviolet irradiation (UV-C) treatment of Dean-vortex technology on pineapple-mango juice blend microbial safety. Non-thermal alternative treatment of UV-C known to be promising in juice processing but low penetration depth in opaque liquid resulted in enhancement of treatment using dean vortex. Dean vortex promotes mixing in helically arranged treatment tube. Two pump frequency was selected ( 40 and $45 \mathrm{~Hz}$ ) to be performed on pineapple-mango juice blend at blending ratio of $70 \%$ pineapple and $30 \%$ mango. The flow regimes inside the polyfluoroalcoxy (PFA) tube behave as turbulence as the effect of dean vortex for both flow rates of the pump which brought the targeted microorganism closer towards light source relatively improve treatment efficiency. Pathogenic E. coli O157: $\mathrm{H} 7$ that can cause fatality was inoculated into pineapple-mango juice blends. This study shows that at a UV-C dosage of $8.38 \mathrm{~mJ} / \mathrm{cm}^{2}$ able to reduce E. coli $\mathrm{O} 157$ : $\mathrm{H} 7$ more than $5 \mathrm{log}$ reduction. Although UV-C treatment unable to fully disinfect yeast and mould counts in pineapple-mango juice blend, the detection colony was still under the permissible limit $(1.26 \log \mathrm{CFU} / \mathrm{mL})$. These proved that UV-C treatment with the implementation of dean-vortex technology able to meet the microbial load safety limit comparable to commercialize practice using thermal pasteurization.
\end{abstract}

\section{Introduction}

Josapine pineapple (Ananas comosus) and Chok Anan mango (Mangifera indica. L.) are among popular tropical fruit that widely planted in Malaysia. Due to the strong taste of pineapple, pineapple often blends together with other fruit (Jan and Masih, 2012) consequently, promoting new juice product. In contrast, mango is known for its sweet but easily deteriorate as an effect of storage and temperature (Raymundo et al., 2009; Khaliq et al., 2016). Chok Anan mango is a seasonal fruit but can be obtained almost throughout the year with harvesting time in May, June and August (Santhirasegaram et al., 2013; Santhirasegaram et al., 2015). The blending of pineapple and mango will results in new product development and reduce the dependency of seasonal stock.

Juice is defined as a product of direct consumption that obtained either by pressing or diffusion methods of fruits (British Soft Drinks Association, 2016). Whereas, fruit juice blend define as mixture of different species of puree juices with or without the addition of sugar (Bates et al., 2001; Lozano, 2006). Bhardwaj and Pandey (2011) added that juice blend extracted from two or more different types of fruits, puree or the edible part of fruit or any concentration still denoted as juice. Thus, any combination of liquid extracted from different species of fruits will be denoted as fruit juice as long as it meets the properties of fruit juice. At early years fruit juice intended as fresh consumption, but due to several outbreaks, FDA regulates that a $5 \log$ reduction of pertinent microorganism must be achieved in fruit juice product (Kahraman et al., 2017). E. coli O157: $\mathrm{H} 7$ is the most reported outbreak in unpasteurised fruit juice (Aneja et al., 2014). Due to the arising awareness of food safety, it is mandatory for fruit juice to be pasteurized either by thermal or non-thermal means of juice processing. Thermal pasteurization is the most common method used commercially worldwide in manufacturing fruit juice products due to its broad ability in preserving 
Table 1. Non-thermal treatments on fruit juice blend

\begin{tabular}{|c|c|c|c|c|}
\hline $\begin{array}{l}\text { Non-thermal } \\
\text { treatment }\end{array}$ & Juice blend & Processing conditions & Key finding (s) & References \\
\hline \multirow{2}{*}{$\begin{array}{l}\text { Pulsed electric } \\
\text { field (PEF) }\end{array}$} & Apple-cranberry & $\begin{array}{c}18 \mathrm{~Hz} ; 34 \mathrm{kV} / \mathrm{cm} ; 1 \mu \mathrm{s} ; 20^{\circ} \\
\mathrm{C}\end{array}$ & $\begin{array}{l}E . \text { coli }(\mathrm{K} 12 \mathrm{DSM} 1607) \\
\text { reduce to } 4 \log \text { reduction }\end{array}$ & Palgan et al. (2011) \\
\hline & Carrot-orange & $\begin{array}{c}18 \mathrm{~Hz} ; 24 \mathrm{kV} / \mathrm{cm} ; 1 \mu \mathrm{s} ; \\
89 \mu \mathrm{s} ;<49^{\circ} \mathrm{C}\end{array}$ & $\begin{array}{l}\text { PME not fully inactive } \\
\text { (14\% of inactivation) }\end{array}$ & Caminiti et al. (2012) \\
\hline \multirow{4}{*}{$\begin{array}{l}\text { High hydrostatic } \\
\text { pressure }\end{array}$} & $\begin{array}{l}\text { Apple-beetroot-carrot } \\
\text {-ginger-lemon }\end{array}$ & $\begin{array}{c}400 \text { to } 600 \mathrm{MPa} ; 0 \text { to } 300 \\
\mathrm{~s} ; 11^{\circ} \mathrm{C}\end{array}$ & $\begin{array}{c}\text { Patulin decrease } 45 \mathrm{ppb} \\
(0.29 \mu \mathrm{M}) \text { treated at } 600 \\
\mathrm{MPa} \text { for } 300 \mathrm{~s}\end{array}$ & Hao et al. (2016) \\
\hline & $\begin{array}{l}\text { Apple-mint- } \\
\text { pineapple }\end{array}$ & $\begin{array}{c}400 \text { to } 600 \mathrm{MPa} ; 0 \text { to } 300 \\
\mathrm{~s} ; 11^{\circ} \mathrm{C}\end{array}$ & $\begin{array}{c}\text { Patulin decrease } 48 \mathrm{ppb} \\
(0.31 \mu \mathrm{M}) \text { treated at } 600 \\
\mathrm{MPa} \text { for } 300 \mathrm{~s}\end{array}$ & Hao et al. (2016) \\
\hline & Jucara-mango & $600 \mathrm{MPa} ; 5 \mathrm{~min} ; 25^{\circ} \mathrm{C}$ & $\begin{array}{l}\text { No changes in } \\
\text { anthocyanin content }\end{array}$ & Moreira et al. (2017) \\
\hline & Orange-sweet pepper & $550 \mathrm{MPa} ; 5 \mathrm{~min} ; \sim 25^{\circ} \mathrm{C}$ & $\begin{array}{c}4 \log \text { reduction of total } \\
\text { aerobic bacteria, yeast } \\
\text { and molds }\end{array}$ & Xu et al. (2015) \\
\hline \multirow[b]{2}{*}{ Sonication } & $\begin{array}{l}\text { Blueberry-orange- } \\
\text { pomegranate }\end{array}$ & $\begin{array}{c}130 \mathrm{~W} ; 60 \% ; 20 \mathrm{kHz} ; 4 \\
\text { and } 6 \mathrm{~min} ;<40^{\circ} \mathrm{C}\end{array}$ & $\begin{array}{l}\text { Inactivation of yeast } W \text {. } \\
\text { anomalus (DSM 70130) }\end{array}$ & $\begin{array}{l}\text { Bevilacqua et al. } \\
\qquad(2014)\end{array}$ \\
\hline & Mango-papaya & $\begin{array}{c}400 \mathrm{~W}, 24 \mathrm{kHz} ; 100 \% ; 20 \\
\text { and } 160 \mathrm{~s}\end{array}$ & $\begin{array}{l}84 \% \text { to } 91 \% \text { retention of } \\
\text { ascorbic acid and higher } \\
\text { carotenoid content }\end{array}$ & $\begin{array}{c}\text { Carbonell-Capella et } \\
\text { al. (2016) }\end{array}$ \\
\hline Ultraviolet light & Carrot-orange & $10.62 \mathrm{~J} / \mathrm{cm}^{2} ; 1 \mathrm{~min}$ & 18\% PME inactivation & Caminiti et al. (2012) \\
\hline \multirow[t]{2}{*}{ Pulsed light } & Apple-cranberry & $1.213 \mathrm{~J} / \mathrm{cm}^{2}$ & $\begin{array}{c}3 \text { and } 4 \text { log reduction of } \\
\text { E. coli (K } 12 \text { DSM 1607) } \\
\text { and } P . \text { fermentans (DSM } \\
70090 \text { ) respectively }\end{array}$ & Palgan et al. (2011) \\
\hline & Carrot-orange & $3.3 \mathrm{~J} / \mathrm{cm}^{2} ; 360 \mu \mathrm{s} ;<30^{\circ} \mathrm{C}$ & $\begin{array}{c}113 \% \text { PME residual } \\
\text { activity }\end{array}$ & Caminiti et al. (2012) \\
\hline $\begin{array}{l}\text { Manothermosonic } \\
\text { ation }\end{array}$ & Apple-carrot & 100 to $300 \mathrm{kPa} ; 15-75 \mathrm{~s}$ & $\begin{array}{c}5 \text { log reduction of } E \text {. coli } \\
\mathrm{O} 157: \mathrm{H} 7 \text { in } 30 \mathrm{~s} \text { for } \\
\text { treatment at } 60^{\circ} \mathrm{C}\end{array}$ & Kahraman et al. (2017) \\
\hline
\end{tabular}

fruit juice (Goh et al., 2012). However, the quality of fruit juice such as the bioactive compound, nutrients and sensorial properties greatly degrade after thermal pasteurization as the effect of temperature (Kaya et al., 2015). Thus, alternative non-thermal treatment such as high-pressure processing, pulsed electric field, sonication and ultraviolet irradiation (Polydera et al., 2003; Moody et al., 2014; Koutchma et al., 2016; Roobab et al., 2018) was widely explored and studied to minimized the drawbacks of thermal pasteurization. Table 1 summarized the used of non-thermal technology on fruit juice blend. In term, of microbial inactivation high pressure processing (HPP) on orange-sweet pepper juice blend resulted with $4 \log$ reduction of total aerobic bacteria, yeast and moulds (Xu et al., 2015), whereas sonication treatment on blueberry-orange-pomegranate juice blend was less effective in yeast inactivation (Bevilacqua et al., 2014). Pulsed light treatment on apple -cranberry juice blend shows 3 and $4 \log$ reduction of $E$. coli (K 12 DSM 1607) and P. fermentans (DSM 70090) respectively. Based on the prior research, study on microbial inactivation of juice blend using ultraviolet irradiation (UV-C) treatment is still limited. Thus, the present study is intended to study the effectiveness of
UV-C treatment on pineapple-mango juice blend. Through numerous prior research, UV-C shows minimal degradation effect on single fruit juice quality attributes (Shah et al. 2016), which promising as an alternative to thermal pasteurization. Besides, compared to other nonthermal technology of PEF, HPP the treatment and equipment cost of UV-C treatment is minimal which can be done in ambient temperature (Rosnah et al., 2013).

UV-C treatment denotes as non-ionizing radiation, which is chemical free and ecologically friendly (Gómez -López et al., 2012) done at germicidal wavelength ranges from 200 to $280 \mathrm{~nm}$ (Teja et al., 2017) with $254 \mathrm{~nm}$ is the best wavelength in killing the microorganism (Santhirasegaram et al., 2015). However, penetration of UV-C light on the liquid foods especially opaque liquid is low due to the high UV light absorption and scattering (Koutchma, 2009), especially in turbid juice. Thus, application of Dean-vortex technology extensively explored to overcome the limitation. Deanvortex technology in UV-C introduced mixing inside the coiled tube through secondary flow (centrifugal force) that perpendicular towards axial fluid direction as an effect of channel curvature (Chandratilleke et al., 2012; 
Fsadni et al., 2016). The effect of UV-C treatment on the microbe inactivation of pineapple-mango juice blend is yet to be discussed elsewhere. Single mango and pineapple juice both different in quality in which the blend of pineapple and mango together will result with juice quality different from their single juice counterpart. The effectiveness of UV-C treatment on microorganism inactivation depends greatly on juice turbidity in which, study by Kamarul Zaman et al. (2016) on pineapplemango juice blend at blending ratio of $70 \%$ pineapple and $30 \%$ mango showed that of pineapple-mango juice blend ( $438 \pm 1.00 \mathrm{NTU})$ less turbid than single mango juice $(798 \pm 1.00 \mathrm{NTU})$. Thus, this intended study was done to investigate the inactivation of $E$. coli $\mathrm{O} 157$ : $\mathrm{H} 7$ (as selected pathogenic bacteria) by using UV-C of Dean -vortex technology in the pineapple-mango juice blend. Besides, the blend of pineapple-mango juice can be marketed as super juice as mango is regarded as super fruit. Lopez (2014) supported that, the blending of traditional fruit juice with exotic fruit promotes the development of juice with super fruit label. Therefore, the use of ultraviolet irradiation treatment on pineapplemango juice blend may preserve the quality and nutritional content of juice as well as enhance the commercial value of the tropical fruit of Malaysia. Hashem et al. (2014) and Huang et al. (2009) added that consumer demands for functional foods with an excellent source of antioxidants and good organoleptic properties increase the interest of fruit juice blend in the market.

\section{Materials and methods}

\subsection{Pineapple-mango juice blend preparation}

Josapine pineapple and Chok Anan mango were obtained from the local retailer in Selangor. Both fruits were purchased at their commercial maturity. After cleaning, peeling and cutting pineapple and mango juice were extracted separately using juice extractor (Power Juice Smartshop, TM US) without the addition of water. In order to minimize the cloudiness and turbidity of fruit juice both pineapple and mango juice was centrifuge to separate the sediment from the juice. Besides, the centrifugation process was added due to the thick creamy -like of the extracted mango which made it unsuitable to be mixed together with pineapple. Both pineapple and mango juice were centrifuged separately at $8000 \mathrm{rpm}$ for 15 mins (Benchtop Centrifuge, Universal 320/320 R, Hettich Zentrifugen, Germany) (Santhirasegaram et al., 2015) and filtered with muslin cloth afterward. The juice then mixed together at blending ratio of $70 \%$ pineapple and $30 \%$ mango as it gives the best quality of juice after blending, as stated by Kamarul Zaman et al. (2016).

\subsection{E. coli O157: $\mathrm{H} 7$ inoculation}

E. coli O157: H7 was obtained in Tryptic Soy Agar (TSA) from Bacteriological Food Safety Laboratory, Food Science and Technology Faculty, Universiti Putra Malaysia. The colonies of E. coli O157: H7 was then cultured in Tryptic Soy Broth by taking a loop of the colony. The remaining colonies in the TSA kept refrigerated at $4^{\circ} \mathrm{C}$ for further use. Figure 1 shows the inoculation step of E. coli O157: H7. The cultured colonies were incubated at $37^{\circ} \mathrm{C}$ for 24 hrs (Gayán et al., 2011) to give time for bacteria to replicates and regrowth. Next, $10 \mathrm{~mL}$ of the stock culture was taken and centrifuged at $500 \mathrm{rpm}$ Benchtop Centrifuge, Universal 320/320 R. Hettich Zentrifugen, Germany) to obtain the cell pellet. Cell pellet then washed with $0.85 \%$ sodium chloride $(\mathrm{NaCl})$ (Tosun and Gönül, 2006). To ensure the presence of E. coli O157: $\mathrm{H} 7$ serial dilution was done using $0.1 \%$ peptone water (range of $10^{-1}$ to $10^{-5}$ ). TSA and sorbitol McConkey agar (SMAC) (DifcoTM, Dickinson and Company, USA) were used for the detection of E. coli O157: H7. Both plates incubated at $37^{\circ} \mathrm{C}$ for $24 \mathrm{hrs}$. E. coli $\mathrm{O} 157$ : $\mathrm{H} 7$ colonies observed will be pink in colour on the SMAC agar and colourless on TSA plate. After ensuring the presence of E. coli O157: H7 inside the stock culture, the bacteria inoculated into pineapple-mango juice blend. The inoculated juice sample then, refrigerated for an hour to before preservation treatment was done. The initial counts of the microorganism inside the pineapple-mango juice blend were analysed in serial dilution methods in triplicate.

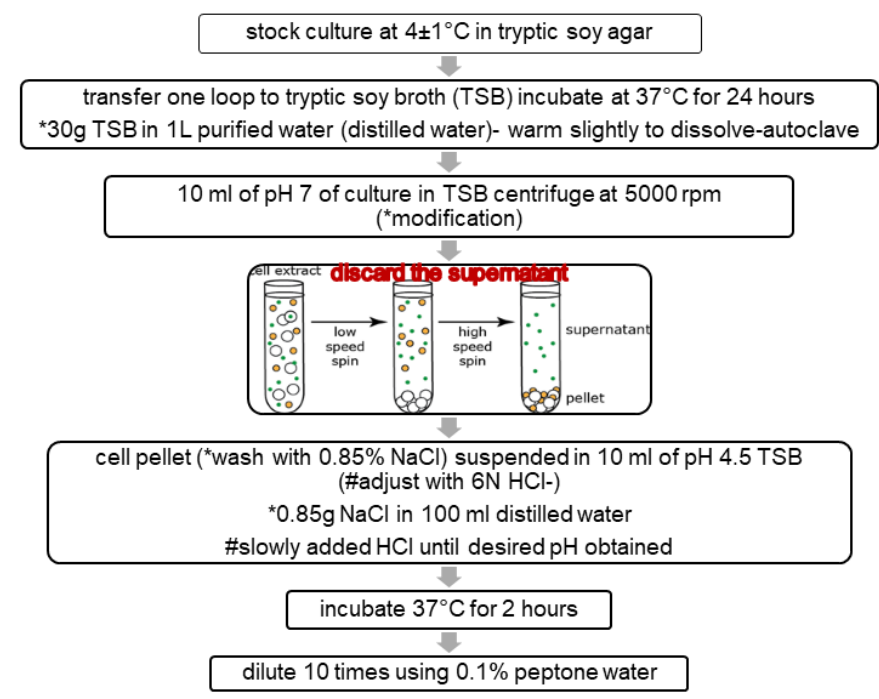

Figure 1. E. coli $\mathrm{O} 157: \mathrm{H} 7$ stock preparation

\subsection{Microbiological analysis}

Total plate counts (TPC) and Yeast and Mould counts (YMC) were also evaluated in this study. Plate count agar (Merk, Germany) was used for TPC plating and the plate was incubated at $25 \pm 2^{\circ} \mathrm{C}$ for 2 days. YMC 
was done through plating on Dichloron rose Bengal Chloramphenicol (DRBC) agar and incubated for 5 days at $37^{\circ} \mathrm{C}$. All experiments were done in triplicate.

The log reduction of microbial counts in pineapplemango juice blend was calculated as follows:

Log reduction $\mathrm{CFU} / \mathrm{ml}=$ Initial $\log$ counts before treatment - Final log counts after treatment

\subsection{Sample calculation for log reduction CFU/ml after $U V-C$ treatment}

The Initial log counts of microorganism in pineapple -mango juice blend was calculated as:

Log (total number of colonies $\times$ dilution factor)/volume culture plate.

Taking the Total plate counts (TPC) as example, the initial total number of colonies of aerobic microorganism were 446 with a dilution factor of $10^{5}$ and volume of culture plate of 0.1 . The final total number of colonies after UV-C treatment was 0 colony with dilution factor of $10^{1}$ and 0.1 volume culture plate. The log reduction $\mathrm{CFU} / \mathrm{ml}$ then determine as follows:

$$
\begin{aligned}
\log \text { reduction } \mathrm{CFU} / \mathrm{mL}= & 7.65 \mathrm{Log} \mathrm{CFU} / \mathrm{mL}-0 \mathrm{Log} \\
& \mathrm{CFU} / \mathrm{mL} \\
= & 7.65 \mathrm{Log} \text { reduction } \mathrm{CFU} / \mathrm{mL}
\end{aligned}
$$

\subsection{Ultraviolet Irradiation $(U V-C)$ treatment}

Malaysia patent (PI201203186) ultraviolet reactor was used to treat pineapple-mango juice blend. A similar reactor was used to treat single pineapple (Mansor et al., 2014; Mansor, et al., 2017), tamarind (Mohd-Hanif et al., 2016) and lime (Mohd-Hanif et al., 2016) juice. The reactor consists of 6 quartz sleeve low mercury lamps (Philips, Malaysia) with 5 of the lamp was occupied with polyfluoroalcoxy (PFA) coiled onto the lamp. UV radiometer was installed in each lamp to measure the irradiance intensity of the lamp that will later use to calculate the UV-C dosage. The schematic diagram of the ultraviolet reactor as illustrated in Figure 2. In the present study, only one coiled lamp and the middle lamp was used in order to test the efficiency of the ultraviolet reactor following the previous study by Mansor et al. (2014) and Mansor et al. (2017). A total of 5 L of pineapple-mango juice blend inside the feed tank flowed into the rotary lobe pump into PFA tube that helically arranged around UV lamp. The time taken for the juice to flow out from the reactor to the collecting tank was taken manually using stop watch. The UV-C dosage was determined using equation as indicate by Mansor et al. (2017). The irradiance intensity was obtained directly from the UV radiometer, while the residence time distribution obtained by dividing the volume of PFA tube $\left(0.1 \mathrm{~m}^{3}\right)$ with juice flow rate.
Dose $\left(\mathrm{mJ} / \mathrm{cm}^{2}\right)=$ Irradiance intensity $\left(\mathrm{mW} /\left(\mathrm{cm}^{2}\right)\right) \times$ Residence time distribution (RTD) (s)

Other parameter that important for ultraviolet irradiation treatment with dean-vortex technology is Dean number (De) (Moulin et al., 1996):

$D e=\operatorname{Re} \sqrt{\frac{D i}{D z}}$

Where Di and Dz are internal diameter of tube $(0.00165$ $\mathrm{m})$ and coiled diameter $(0.0032 \mathrm{~m})$ respectively.

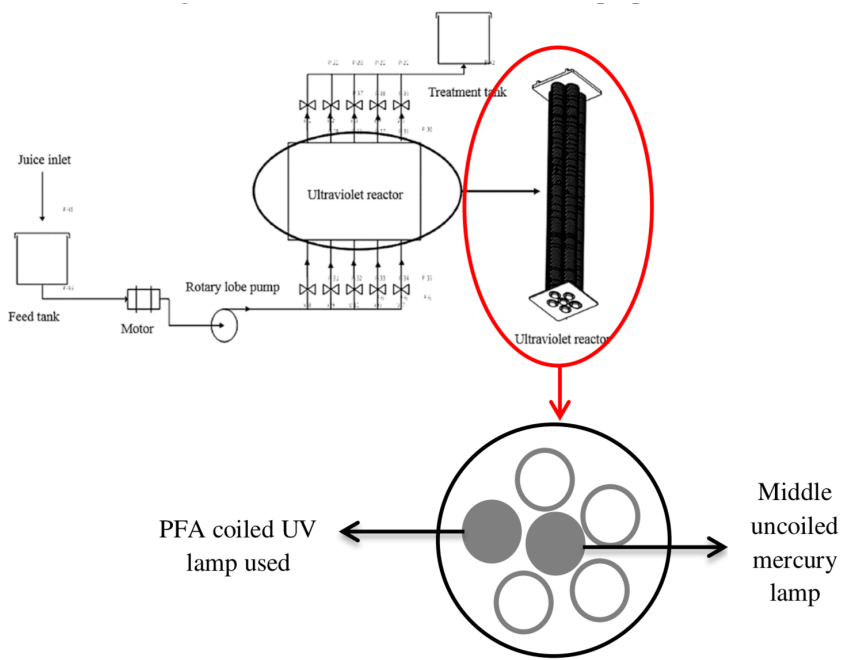

Figure 2. Schematic diagram of the ultraviolet reactor (Adapted from (Mohd-Hanif, Shamsudin, and Adzahan (2016))

\subsection{Thermal pasteurisation}

Thermal pasteurisation was done as a comparison to the non-thermal treatment of UV-C done on pineapplemango juice blend. Treatment was done at $90^{\circ} \mathrm{C}$ for 5 mins using batch pasteuriser (P9000, Elecrem, France). Pineapple-mango juice blend was tightly capped in the sterilised glass bottle before submerged into the pasteuriser using water bath system to minimize the effect heat on juice quality (Hounhouigan et al., 2014).

All the experimental work was done in triplicate.

\section{Results and Discussion}

3.1 UV-C dosage for inactivation of E. coli $\mathrm{O} 157: \mathrm{H} 7$ in pineapple-mango juice blend

Pineapple-mango juice blend of $\mathrm{pH} 4.32 \pm 0.02$ with turbidity value of 438 NTU was treated with the ultraviolet reactor at 2 different pump frequency (40 and $45 \mathrm{~Hz}$ ). The selected pump frequency will later affect the flow rate of the juice flowing inside the UV-C reactor. Table 2 shows the parameters obtained at the two different pump frequency selected.

Juice pumped at lower pump frequency resulted in lower flow rate. Based on Table 1, juice pump at $40 \mathrm{~Hz}$ 
Table 2. UV-C parameters at a different pump flow

\begin{tabular}{cccccc}
\hline Pump frequency $(\mathrm{Hz})$ & Flow rate $(\mathrm{L} / \mathrm{s})$ & RTD(s) & UV-C dose $\left(\mathrm{mJ} / \mathrm{cm}^{2}\right)$ & Reynolds no (Re) & Dean number $(\mathrm{De})$ \\
\hline 40 & $0.012 \pm 0.001^{\mathrm{a}}$ & $8.65 \pm 0.003^{\mathrm{a}}$ & $8.38 \pm 0.079^{\mathrm{a}}$ & $5093 \pm 1.357^{\mathrm{a}}$ & $995.73 \pm 0.668^{\mathrm{a}}$ \\
45 & $0.014 \pm 0.001^{\mathrm{a}}$ & $7.28 \pm 0.003^{\mathrm{b}}$ & $6.47 \pm 0.059^{\mathrm{b}}$ & $6053 \pm 2.969^{\mathrm{b}}$ & $1183.37 \pm 0.971^{\mathrm{b}}$ \\
\hline
\end{tabular}

$\mathrm{RTD}=$ residence time distribution. A value followed by the same letter within the same column not significantly different from each other $(\mathrm{p}>0.05)$.

having juice flow rate of $0.012 \mathrm{~L} / \mathrm{s}$ while at $45 \mathrm{~Hz}$ the flow rate of juice was slightly higher at $0.014 \mathrm{~L} / \mathrm{s}$. Flow rate affects the RTD and UV-C dosage induced as lower flow rate resulted with longer residence time distribution (RTD) and higher UV-C dosage. The present study shows consistency with the prior studies by Mansor et al. (2014), and Mohd-Hanif et al. (2016) on single pineapple and lime juice respectively, in which at lower pump frequency selected the UV-C dosage was higher. Such phenomenon happened due to the longer time of interaction for the juice flowing with the light source. Mansor et al. (2014) added that high frequency resulted with lower RTD and relatively caused the juice flow rate to be higher, hence lowering the UV-C dose.

The parameter of flow rate later affects the flow pattern inside the PFA coiled tubing of the UV-C reactor. Higher flow rate $(0.014 \mathrm{~L} / \mathrm{s})$ resulted with more turbulence flow $(6053 \pm 2.969)$ of pineapple-mango juice blend inside the PFA coiled tubing as tabulated in Table 2. The Reynolds number (Re) denoted as turbulence at value $>4000$ and recognized as laminar at value $<2000$. The present study shows deviation from Mansor et al. (2014) as UV-C treatment on single pineapple juice using the same UV-C reactor having laminar flow pattern (ranging from $396 \pm 10.4$ to $610 \pm 15.4$ ) at the UV$\mathrm{C}$ dose ranging from $10.10 \pm 0.7$ to $13.75 \pm 1.5 \mathrm{~mJ} / \mathrm{cm}^{2}$. Laminar flow pattern may cause inconsistency of UV-C dose distribution along the ultraviolet reactor (Koutchma et al., 2004). Pineapple-mango juice blend exhibit turbulent flow pattern for both designated pump frequency which may be contributed by the juice properties of turbidity. Pineapple-mango juice blend was less turbid (438 NTU) compared to single pineapple juice which having turbidity value of $1441.25 \pm 43.45$ NTU (Shamsudin et al., 2014). The turbidity of pineapple-mango juice blend was reduced during processing by centrifugation method. Juice turbidity affects the UV-C treatment efficiency due to the scattering of light and shadowing effect on microbes (Mohd Adzahan et al., 2011). Turbulence flow more effective in microorganism disinfection as the targeted microorganism brought closer to the ultraviolet light source (Koutchma et al., 2007). Apple juice and apple cider recorded a higher log reduction of E. coli O157: H7 in turbulent treatment compared to laminar flow treatment (Sauer and Moraru, 2009).

In the Dean-vortex technology of UV-C reactor, an internal mixing promotes better microorganism inactivation. The dean effect during the UV-C treatment was represented by the Dean number (De). At higher Re, the dean effect was more prominent. Based on data obtained in Table 2, at Re value of $5093 \pm 1.357$ and $6053 \pm 2.969$, the De values were $995.73 \pm 0.668$ and $1183.37 \pm 0.971$ respectively. A similar trend of De increase with the increment of Re value observed in the study by Mansor et al. (2014) and Müller et al. (2011) on single pineapple and apple juice. De value $>100$ indicate the greater effect of mixing (Johnson and Kamm, 1986) which increased the momentum, mass transfer, heat transfer and Reynolds number which contribute to decrement in axial dispersion (Irudayaraj, 2002). Despite the greater mixing effect obtained at higher Re value in the present study, the treatment at UV-C dosage of $8.38 \mathrm{~mJ} / \mathrm{cm}^{2}$ (obtained at lower Re value of $5093 \pm 1.357$ ) was selected as the best dosage due to its greater microbial inactivation. Too turbulent flow pattern may cause instability of fluid flow thus, mixing of fluid unable to be done perfectly (Mansor et al., 2014; MohdHanif et al., 2016). Nikolof et al. (2013) added that uniform mixing inside the ultraviolet reactor is crucial for effective irradiation effect on the fluid treated.

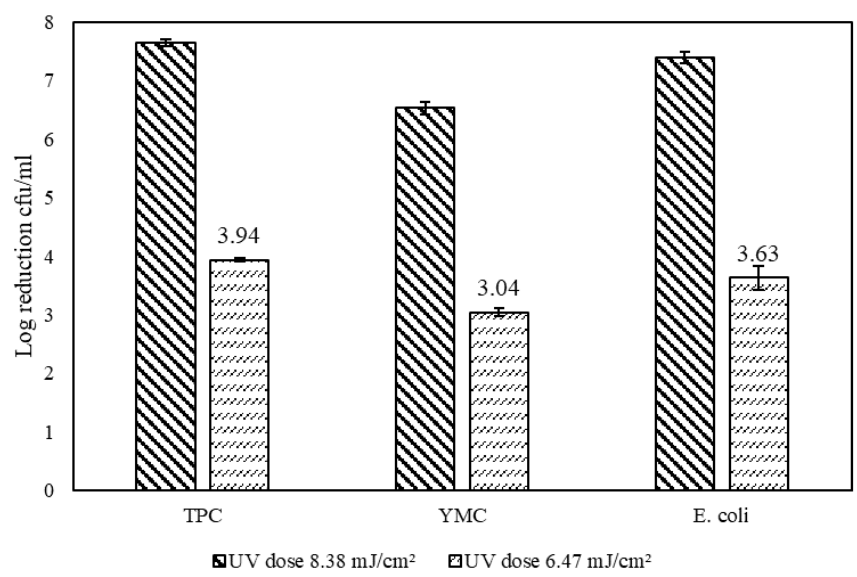

Figure 3. Microorganism inactivation at the different UV-C dosage (TPC, YMC and E. coli are total plate count, yeast and mould count, and E. coli $\mathrm{O} 157$ : $\mathrm{H} 7$ respectively)

Referring to Figure 3 on inactivation of microorganism at UV-C dosage of $8.38 \mathrm{~mJ} / \mathrm{cm}^{2}$ and 6.47 $\mathrm{mJ} / \mathrm{cm}^{2}$ was greater. The unstable turbulence flow at higher pump frequency caused the microorganism unable to be fully exposed to the UV-C light source thus, reduced the killing rate of the microorganism (MohdHanif et al., 2016). E. coli O157: $\mathrm{H} 7$ initial counts of 7.4 $\log \mathrm{CFU} / \mathrm{mL}$ was completely inactive resulted with 7.4 
$\log$ reduction after treatment at UV-C dose of $8.38 \mathrm{~mJ} /$ $\mathrm{cm}^{2}$. Previous study by Keyser et al. (2008) on inactivation of E. coli O157: $\mathrm{H} 7$ in apple juice at UV-C dosage of $14 \mathrm{~mJ} / \mathrm{cm}^{2}$ resulted with $6.65 \mathrm{log}$ reduction which meets the FDA regulation of $5 \log$ reduction of a pertinent pathogen in fruit juice (FDA, 2004) showing the effectiveness of ultraviolet irradiation treatment in pathogenic bacteria inactivation. The present study resulted with lower UV-C dosage needed by pineapplemango juice blend to achieve more than 5 log reduction of microorganism compared to the study by Keyser et al. (2008) due to the centrifugation process done during juice preparation to reduce the limitation of ultraviolet treatment on turbid and high opacity fluid. Opaque juice having absorption coefficient ranging 40 to $100 \mathrm{~cm}^{-1}$, will be unable to meet the requirement of $5 \log$ reduction of the pertinent microorganism (Koutchma, 2009). In the present study, however, the opacity of the pineapplemango juice blend was not measured. Higher turbidity juice resulted with high opacity in which in the present study the juice turbidity value categorized as less turbid as the value is less than $600 \mathrm{NTU}$ (Benitez et al., 2007a; Benitez et al., 2007b). Caminiti et al. (2012) supported that apple juice only requires a low dosage of ultraviolet treatment compare to orange juice to effectively inactive E. coli $\mathrm{K} 12$ as apple juice was less turbid than orange juice.

The present study resulted with YMC log reduction at UV-C dosage of $8.38 \mathrm{~mJ} / \mathrm{cm}^{2}$ was the lowest compared to TPC and E. coli O157: H7, but still more than $5 \log$ reduction. While, at $6.47 \mathrm{~mJ} / \mathrm{cm}^{2} \mathrm{UV}-\mathrm{C}$ dose, YMC (3.04 log reduction), TPC (3.94 log reduction) and E. coli O157: $\mathrm{H} 7$ (3.63 log reduction) log reduction was under the permissible limit indicate inadequate dosage induce for the treatment. Franz et al. (2009) study on cloudy apple juice applying the dean vortex technology of ultraviolet irradiation treatment also obtained similar observation of lower log reduction of yeast and lactic acid ( $3 \log$ reduction) as compared to E. coli (5 log reduction). According to Bhat, Kamaruddin et al. (2011) due to the bigger DNA structure of yeast it exhibits greater resistant towards chemical changes which require a higher dosage to be inactivated. However, UV-C treatment at $0.032 \mathrm{~W} / \mathrm{cm}^{2}$ resulted with no detection of a microorganism of yeast and mould, and mesophilic bacteria in apple juice (Juarez-Enriquez et al., 2016) indicate the dosage induce was enough to inactive the microorganism below the detection limit.

\subsection{Comparison with thermal pasteurization}

Thermal pasteurization was known to be widely used in juice processing industry as it proven to be effective to kill microorganism in fruit juice. Table 3 shows the initial microbial counts in pineapple-mango juice blends before and after treatment with thermal and UV-C. From the data obtained, UV-C treatment with dean vortex technology was effective in inactivation of $E$. coli $\mathrm{O} 157$ : $\mathrm{H} 7$ in pineapple-mango juice blend comparable to thermal pasteurization. As far as the author's concern, there was no reported study on inactivation of $E$. coli O157: H7 on juice blend (pineapple-mango juice blend specifically) applying the dean vortex technology, however, several studies on single fruit juices were available. E. coli $\mathrm{O} 157: \mathrm{H} 7$ effectively inactive up to 5 log reduction in apple cider (Basaran et al., 2004), orange (Oteiza et al., 2010), clear apple juice (Gabriel, 2012; Usaga et al., 2017) and tamarind juice (MohdHanif et al., 2016) after treatment with UV-C irradiation with dean vortex technology.

Based on the results obtained in Table 3, the yeast and mould after UV-C treatment was not fully inactive due to the higher resistant of yeast and mould towards UV-C light. However, the yeast and mould count (YMC) was still lower than $5 \log \mathrm{CFU} / \mathrm{mL}$. The effectiveness of UV-C on cell destruction of microorganism depends on the sensitivity of microorganism towards the UV-C light as different microorganism reacts differently (Tran and Farid, 2004). As mention earlier, yeast and mould having DNA size bigger than another microorganism of $E$. coli O157: $\mathrm{H} 7$ and aerobic microorganism which scatter and block the UV-C penetration.

\section{Conclusion}

UV-C treatment at UV-C dosage of $8.38 \pm 0.079 \mathrm{~mJ} /$ $\mathrm{cm}^{2}$ able to fully inactive the E. coli $\mathrm{O} 157: \mathrm{H} 7$ in pineapple-mango juice blend. The dean vortex technology helps to promote mixing in the PFA coiled tube which relatively improves the efficiency of microbial inactivation. The present study can be improved in the future by varying the selection of pump frequency to increase the inactivation rate of yeast and mould that shows greater defends towards UV-C light. Besides, the effect of juice optical density and viscosity may be studied as the information can be used to increase the effectiveness of $\mathrm{UV}-\mathrm{C}$ treatment. Comparison with thermal pasteurization shows that UV-

Table 3. Microbial counts at difference pasteurisation treatment

\begin{tabular}{lccc}
\hline \multicolumn{1}{c}{ Treatment } & TPC $(\log \mathrm{CFU} / \mathrm{mL})$ & YMC $(\log \mathrm{CFU} / \mathrm{mL})$ & E. coli O157: H7 $(\log \mathrm{CFU} / \mathrm{mL})$ \\
\hline Fresh juice & $7.65 \pm 0.052$ & $7.79 \pm 0.102$ & $7.40 \pm 0.096$ \\
UV-C $\left(8.38 \mathrm{~mJ}^{2} \mathrm{~cm}^{2}\right)$ & 0 & $1.26 \pm 0.107$ & 0 \\
Thermal pasteurization $\left(90^{\circ} \mathrm{C}, 5 \mathrm{~min}\right)$ & 0 & 0 & 0 \\
\hline
\end{tabular}

(TPC and YMC are total plate count, yeast and mould count respectively) 
C irradiation treatment with dean vortex technology can be considered to be implemented in juice processing industry in Malaysia as it shows a promising effect on juice safety.

\section{Acknowledgement}

The authors would like to acknowledge the financial support from Universiti Putra Malaysia Grant (GPIPS/2016/9473900).

\section{References}

Aneja, K.R., Dhiman, R., Aggarwal, N.K., Kumar, V. and Kaur, M. (2014). Microbes Associated with Freshly Prepared Juices of Citrus and Carrots. International Journal of Food Science, 2014, 1-7. https://doi.org/10.1155/2014/408085

Basaran, N., Quintero-Ramos, A., Moake, M.M., Churey, J.J. and Worobo, R.W. (2004). Influence of apple cultivars on inactivation of different strains of a Escherichia coli O157: $\mathrm{H7}$ in apple cider by UV irradiation. Applied Environmental Microbiology 70 (10), 6061-6065. https://doi.org/10.1128/ AEM.70.10.6061-6065.2004

Bates, R.P., Morris, J.R. and Crandall, P.G. (2001). Principle and practises small and mediun scale fruit juice processing. FAO Agricultural Services Bulletin No. 146. Rome: FAO

Benitez, E.I., Genovese, D.B. and Lozano, J.E. (2007a). Scattering efficiency of a cloudy apple juice: Effect of particles characteristics and serum composition. Food Research International, 40(7), 915-922. https://doi.org/10.1016/j.foodres.2007.03.004

Benítez, E.I., Genovese, D.B. and Lozano, J.E. (2007b). Effect of $\mathrm{pH}$ and ionic strength on apple juice turbidity: Application of the extended DLVO theory. Food Hydrocolloids, 21(1), 100-109. https:// doi.org/10.1016/j.foodhyd.2006.02.007

Bevilacqua, A., Speranza, B., Campaniello, D., Sinigaglia, M. and Corbo, M.R. (2014). Inactivation of spoiling yeasts of fruit juices by pulsed ultrasound. Food Bioprocess Technology, 7, 21872197. https://doi.org/10.1007/s11947-013-1178-5

Bhardwaj, R.L. and Pandey, S. (2011). Juice Blends-A Way of Utilization of Under-Utilized Fruits, Vegetables, and Spices: A Review. Critical Reviews in Food Science and Nutrition, 51(6), 563-570. https://doi.org/10.1080/10408391003710654

Bhat, R., Kamaruddin, N.S.B.C., Min-Tze, L. and Karim, A.A. (2011). Sonication improves Kasturi lime (Citrus microcarpa) juice quality. Ultrasonics Sonochemistry, 18(6), 1295-1300. https:// doi.org/10.1016/j.ultsonch.2011.04.002
British Soft Drinks Association (BSDA). (2016). Fruit Juice Technical Guidance. $1^{\text {st }}$ ed., p. 1-36. Retrieved from British Soft Drinks Association (BSDA) website: http://www.britishsoftdrinks.com/write/ MediaUploads/Publications/BSDA_FRUIT_JUICE_GUIDANCE_May_2016.pdf

Caminiti, I.M., Palgan, I., Muñoz, A., Noci, F., Whyte, P., Morgan, D.J. and Lyng, J.G. (2011). The Effect of Ultraviolet Light on Microbial Inactivation and Quality Attributes of Apple Juice. Food and Bioprocess Technology, 5(2), 680-686. https:// doi.org/10.1007/s11947-010-0365-x

Caminiti, I.M., Noci, F., Morgan, D. J., Cronin, D.A. and Lnyg, J.G. (2012). The effect of pulsed electric fields, ultraviolet light or high intensity light pulses in combination with manothermosonication on selected physic-chemical and sensory attributes of an orange and carrot juice blend. Food Bioproduct Process, 90, 442-450. https://doi.org/10.1016/ j.fbp.2011.11.006

Carbonell-Capella, J.M., Buniowska, M., Barba, F.J., Grimi, N., Vorobiev, E., Esteve, M.J. and Frígola, A. (2016). Changes of antioxidant compounds in a fruit juice-Stevia rebaudiana blend processed by pulsed electric technologies and ultrasound. Food Bioprocess Technology, 9, 1159-1168. https:// doi.org/10.1007/s11947-016-1706-1

Chandratilleke, T.T., Nadim, N. and Narayanaswamy, R. (2012). Vortex structure-based analysis of laminar flow behaviour and thermal characteristics in curved ducts. International Journal of Thermal Sciences, 59, 75-86.

https://doi.org/10.1016/

j.ijthermalsci.2012.04.014

FDA. (2004). Guidance for Industry: Juice HACCP Hazards and Controls Guidance First Edition Final Guidance. U.S. Department of Health and Human Services, Food and Drug Administration, Center for Food Safety and Applied Nutrition (CFSAN) Vol. 17. Retrieved from http://www.fda.gov/Food/ GuidanceRegulation/

GuidanceDocumentsRegulatoryInformation/Juice/ ucm072557.htm

Franz, C.M.A.P., Specht, I., Cho, G.S., Graef, V. and Stahl, M.R. (2009). UV-C-inactivation of microorganisms in naturally cloudy apple juice using novel inactivation equipment based on Dean vortex technology. Food Control, 20(12), 1103-1107. https://doi.org/10.1016/j.foodcont.2009.02.010

Fsadni, A.M., Whitty, J.P.M. and Stables, M.A. (2016). A brief review on frictional pressure drop reduction studies for laminar and turbulent flow in helically coiled tubes. Applied Thermal Engineering, 109,334343. 
j.applthermaleng.2016.08.068

Gabriel, A.A. (2012). Inactivation of Escherichia coli O157:H7 and spoilage yeasts in germicidal UV-Cirradiated and heat-treated clear apple juice. Food Control, 25(2), 425-432. https://doi.org/10.1016/ j.foodcont.2011.11.011

Gayán, E., Monfort, S., Álvarez, I. and Condón, S. (2011). UV-C inactivation of Escherichia coli at different temperatures. Innovative Food Science and Emerging Technologies, 12(4), 531-541. https:// doi.org/10.1016/j.ifset.2011.07.008

Goh, S.G., Noranizan, M., Leong, C.M., Sew, C.C. and Sobhi, B. (2012). Effect of thermal and ultraviolet treatments on the stability of antioxidant compounds in single strength pineapple juice throughout refrigerated storage. International Food Research Journal, 19(3), 1131-1136.

Gómez-López, V.M., Koutchma, T. and Linden, K. (2012). Ultraviolet and Pulsed Light Processing of Fluid Foods. Novel Thermal and Non-Thermal Technologies for Fluid Foods, 185-223. https:// doi.org/10.1016/B978-0-12-381470-8.00008-6

Hashem, H., Sharaf, A., Amira, S. and Ibrahim, G. (2014). Changes in Physico-Chemical Quality and Volatile Compounds of Orange-Carrot Juice Blends During storage. Food Science and Quality Management, 33, 21-36.

Hao, H., Zhou, T., Koutchma, T., Wu, F.M. and Warriner, K. (2016). High hydrostatic pressureassisted degradation of patulin in fruit and vegetable juice blends. Food Control 62, 237-242. https:// doi.org/10.1016/j.foodcont.2015.10.042

Hounhouigan, M.H., Linnemann, A.R., Soumanou, M.M. and Van Boekel, M.A.J.S. (2014). Effect of Processing on the Quality of Pineapple Juice. Food Reviews International, 30(2), 112-133. https:// doi.org/10.1080/87559129.2014.883632

Huang, Y., Rasco, B.A. and Cavinato, A.G. (2009). Fruit Juices. In Sun, D.W. (Eds). Infrared Spectroscopy for Food Quality Analysis and Control, p. 355-375. United States of America: Charon Tec Ltd. https:// doi.org/10.1016/B978-0-12-374136-3.00013-4

Irudayaraj, J. (2002). Food Processing Operations Modeling Design and Analysis. Boca Raton: CRC Press.

Jan, A. and Masih, E.D. (2012). Development and Quality Evaluation of Pineapple Juice Blend with Carrot and Orange juice. International Journal of Scientific and Research Publications, 2(8), 22503153.

Johnson, M. and Kamm, R.D. (1986). Numerical studies of steady flow dispersion at low Dean number in a gently curving tube. Journal of Fluid Mechanics, 172, 329-345. https://doi.org/10.1017/ S0022112086001763

Juarez-Enriquez, E., Salmerón, I., Gutierrez-Mendez, N. and Ortega-Rivas, E. (2016). Ultraviolet Irradiation Effect on Apple Juice Bioactive Compounds during Shelf Storage. Foods, 5(1), 10. https:// doi.org/10.3390/foods5010010

Kahraman, O., Lee, H., Zhang, W. and Feng, H. (2017). Manothermosonication (MTS) treatment of applecarrot juice blend for inactivation of Escherichia coli O157:H7. Ultrasonics Sonochemistry, 38, 820-828. https://doi.org/10.1016/j.ultsonch.2016.11.024

Kamarul Zaman, A.A., Shamsudin, R. and Mohd Adzahan, N. (2016). Effect of blending ratio on quality of fresh pineapple (Ananas comosus L.) and mango (Mangifera indica L.) juice blends. International Food Research Journal 23(Suppl.), S101-S106.

Kaya, Z., Yildiz, S. and Ünlütürk, S. (2015). Effect of UV-C irradiation and heat treatment on the shelf life stability of a lemon-melon juice blend: Multivariate statistical approach. Innovative Food Science and Emerging Technologies, 29, 230-239. https:// doi.org/10.1016/j.ifset.2015.03.005

Keyser, M., Muller, I.A., Cilliers, F.P., Nel, W. and Gouws, P.A. (2008). Ultraviolet radiation as a nonthermal treatment for the inactivation of microorganisms in fruit juice. Innovative Food Science and Emerging Technologies, 9(3), 348-354. https://doi.org/10.1016/j.ifset.2007.09.002

Khaliq, G., Mohamed, M.T.M., Ding, P., Ghazali, H.M. and Ali, A. (2016). Storage behaviour and quality responses of mango (Mangifera indica L.) fruit treated with chitosan and gum arabic coatings during cold storage conditions. International Food Research Journal, 23(Suppl.), S141-S148.

Koutchma, T. (2009). Advances in ultraviolet light technology for non-thermal processing of liquid foods. Food and Bioprocess Technology 2, 138-155. https://doi.org/10.1007/s11947-008-0178-3

Koutchma, T., Keller, S., Chirtel, S. and Parisi, B. (2004). Ultraviolet disinfection of juice products in laminar and turbulent flow reactors. Innovative Food Science and Emerging Technologies, 5(2), 179-189. https://doi.org/10.1016/j.ifset.2004.01.004

Koutchma, T., Popović, V., Ros-Polski, V. and Popielarz, A. (2016). Effects of Ultraviolet Light and High-Pressure Processing on Quality and HealthRelated Constituents of Fresh Juice Products. Comprehensive Reviews in Food Science and Food Safety, 15(5), 844-867. https://doi.org/10.1111/1541 
$-4337.12214$

Lozano, J.E (Ed.). (2006). Processing of Fruits: Ambient and Low Temperature Processing. In Fruit Manufacturing: Scientific Basis, Engineering Properties and Deteriorative Reactions of Technological Importance, p. 230. New York: Springer-Verlag

Mansor, A., Shamsudin, R., Adzahan, N.M. and Hamidon, M.N. (2014). Efficacy of Ultraviolet Radiation as Non-thermal Treatment for the Inactivation of Salmonella Typhimurium TISTR 292 in Pineapple Fruit Juice. Agriculture and Agricultural Science Procedia, 2, 173-180. https:// doi.org/10.1016/j.aaspro.2014.11.025

Mansor, A., Shamsudin, R., Mohd Adzahan, N. and Hamidon, M.N. (2017). Performance of UV Pasteurization with Quartz Glass Sleeve on Physicochemical Properties and Microbial Activity of Pineapple Juice. Journal of Food Process Engineering, 40(1), 1-8. https://doi.org/10.1111/ jfpe. 12263

Mohd-Hanif, H.A., Shamsudin, R. and Adzahan, N.M. (2016). UVC dosage effects on the physico-chemical properties of lime (Citrus aurantifolia) juice. Food Science and Biotechnology, 25, 63-67. https:// doi.org/10.1007/s10068-016-0099-2

Mohd-Hanif, H.A., Shamsudin, R. and Mohd Adzahan, N. (2016). Effects of UVC irradiation and thermal treatment on the physico-chemical properties and microbial reduction of clear and turbid tamarind juice. International Food Research Journal, 23 (Suppl.), S107-S112.

Mohd Adzahan, N., Lau, P.L., Hashim, N., Shamsudin, R., Sew, C.C. and Sobhi, B. (2011). Pineapple Juice Production Using Ultraviolet Pasteurisation: Potential Cost Implications. Journal of Agribusiness Marketing, 4(2011), 38-50.

Moody, A., Marx, G., Swanson, B.G. and BermúdezAguirre, D. (2014). A comprehensive study on the inactivation of Escherichia coli under nonthermal technologies: High hydrostatic pressure, pulsed electric fields and ultrasound. Food Control, 37(1), 305-314.

Moulin, P., Rouch, J.C., Serra, C., Clifton, M.J. and Aptel, P. (1996). Mass transfer improvement by secondary flows: Dean vortices in coiled tubular membranes. Journal of Membrane Science, 114, 235-244. https://doi.org/10.1016/0376-7388(95) 00323-1

Moreira, R.M., Martins, M.L., Leita Júnior B.R.D.C.L., Martins E.M.F., Ramos, A.M., Cristianini, M., Campos A.N. da R., Stringheta, P.C., Silva, V.R.O.,
Canuto, J.W., Oliveira, D.C.D., Pereira D.C.D.S. (2017). Development of a jucara and Ubá mango juice mixture with added Lactobacillus rhamnosus GG processed by high pressure. LWT-Food Science and Technology, 77, 259-268. https:// doi.org/10.1016/j.lwt.2016.11.049

Müller, A., Stahl, M.R., Graef, V., Franz, C.M.A.P. and Huch, M. (2011). UV-C treatment of juices to inactivate microorganisms using Dean vortex technology. Journal of Food Engineering, 107(2), 268-275.

https://doi.org/10.1016/ j.jfoodeng.2011.05.026

Nikolof, T., Prakash, M., Cleary, P.W. and Bertolini, J. (2013). Fluid flow in a spiral device used for irradiation of biological fluids. Biotechnology Progress, 29(2), 359-367. https://doi.org/10.1002/ btpr.1676

Oteiza, J.M., Giannuzzi, L. and Zaritzky, N. (2010). Ultraviolet treatment of orange juice to inactivate $E$. coli $\mathrm{O} 157: \mathrm{H} 7$ as affected by native microflora. Food and Bioprocess Technology, 3(4), 603-614. https:// doi.org/10.1007/s11947-009-0194-y

Palgan, I., Caminiti, I. M., Muňoz, A., Noci, F., Whyte, P., Morgan D.J., Cronin D.A. and Lyng, J.G. (2011). Combined effect of selected non-thermal technologies on Escherichia coli and Pichia fermentans inactivation in apple and cranberry juice blend and on product shelf life. International Journal Food Microbiology, 151, 1-6. https:// doi.org/10.1016/j.ijfoodmicro.2011.07.019

Polydera, A.C., Stoforos, N.G. and Taoukis, P.S. (2003). Comparative shelf life study and vitamin $\quad \mathrm{C}$ loss kinetics in pasteurised and high pressure processed reconstituted orange juice. Journal of Food Engineering, 60(1), 21-29. https://doi.org/10.1016/ S0260-8774(03)00006-2

Raymundo, L.C., Ombico, M.T. and de Villa, T.M. (2009). Fruit processing. In Litz, R.E. (Ed.). The Mango: Botany, Production and Uses. 2nd ed., p. 628-640. USA: CAB International. https:// doi.org/10.1079/9781845934897.0628

Roobab, U., Aadil, R.M., Madni, G.M. and Bekhit, A.E.D. (2018). The Impact of Nonthermal Technologies on the Microbiological Quality of Juices: A Review. Comprehensive Reviews in Food Science and Food Safety, 17(2), 437-457. https:// doi.org/10.1111/1541-4337.12336

Rosnah, S., Noranizan, M.A. and Yee, Y.P. (2013). Ultraviolet Technology - an Alternative to Juice Pasteurization. Jurutera. Malaysia: The Institution of Engineers.

Santhirasegaram, V., Razali, Z., George, D.S. and 
Somasundram, C. (2015). Comparison of UV-

$\mathrm{C}$ treatment and thermal pasteurization on quality of Chokanan mango (Mangifera indica L.) juice. Food and Bioproducts Processing, 94(April 2015), 313-321. https://doi.org/10.1016/ j.fbp.2014.03.011

Santhirasegaram, V., Razali, Z. and Somasundram, C. (2013). Effects of thermal treatment and sonication on quality attributes of Chokanan mango (Mangifera indica L.) juice. Ultrasonics Sonochemistry, 20(5), 1276-1282. https://doi.org/10.1016/ j.ultsonch.2013.02.005

Shah, N.N.A.K., Shamsudin, R., Abdul Rahman, R. and Adzahan, N. (2016). Fruit Juice Production Using Ultraviolet Pasteurization: A Review. Beverages, 2 (3), 22. https://doi.org/10.3390/beverages2030022

Shamsudin, R., Mohd Adzahan, N., Pui Yee, Y. and Mansor, A. (2014). Effect of repetitive ultraviolet irradiation on the physico-chemical properties and microbial stability of pineapple juice. Innovative Food Science and Emerging Technologies, 23, 114120. https://doi.org/10.1016/j.ifset.2014.02.005

Teja, C.K., Sanganamoni, S. and Prabhakar, B. (2017). Effect of UV - C Light Treatment on Physicochemical and Bioactive Compounds in Apple and Pineapple Juices, International Journal of Current Microbiology and Applied Science, 6(6), 2321-2333. https://doi.org/10.20546/ ijcmas.2017.606.275

Tran, M.T.T. and Farid, M. (2004). Ultraviolet treatment of orange juice. Innovative Food Science and Emerging Technologies, 5(4), 495-502. https:// doi.org/10.1016/j.ifset.2004.08.002

Usaga, J., Manns, D.C., Moraru, C.I., Worobo, R.W. and Padilla-Zakour, O.I. (2017). Ascorbic acid and selected preservatives influence effectiveness of UV treatment of apple juice. LWT - Food Science and Technology, 75, 9-16. https://doi.org/10.1016/ j.lwt.2016.08.037

Xu, Z., Lin, T., Wang, Y. and Liao, X. (2015). Quality assurance in pepper and orange juice blend treated by high pressure processing and high temperature short time treatment. Innovative Food Science and Emerging Technology, 31, 28-36. https:// doi.org/10.1016/j.ifset.2015.08.001 